\title{
Soil and foliar application of nitrogen for Boro rice (BRRIdhan 29)
}

\author{
S. S. Alam, A. Z. M. Moslehuddin, M. R. Islam and A. M. Kamal \\ Department of Soil Science, Bangladesh Agricultural University, Mymensingh-2202, Bangladesh
}

\begin{abstract}
An experiment was conducted at the Soil Science Field Laboratory of Bangladesh Agricultural University, Mymensingh during Boro season of 2008 with a view to examining the effect of soil and foliar application of urea on the yield and nutrient uptake of BRRIdhan 29 and to evaluate whether urea foliar application (FA) could replace its soil application (SA) in the rice cultivation. The experiment was laid out in a randomized complete block design (RCBD) with eight treatments, each treatment replicated thrice. The treatments were: $\mathrm{T}_{1}$ (control), $\mathrm{T}_{2}$ (282 kg urea ha $\left.{ }^{1} \mathrm{SA}\right), \mathrm{T}_{3}$ (1\% urea solution FA), $\mathrm{T}_{4}\left(2 \%\right.$ urea solution FA), $\mathrm{T}_{5}$ (3\% urea solution FA), $\mathrm{T}_{6}\left(94 \mathrm{~kg}\right.$ urea ha ${ }^{-1} \mathrm{SA}+1 \%$ urea solution $\mathrm{FA}), \mathrm{T}_{7}\left(94 \mathrm{~kg}\right.$ urea ha ${ }^{-1} \mathrm{SA}+2 \%$ urea solution $\left.\mathrm{FA}\right)$ and $\mathrm{T}_{8}\left(94 \mathrm{~kg}\right.$ urea ha ${ }^{-1} \mathrm{SA}+3 \%$ urea solution FA). The results showed that soil and foliar application of nitrogen significantly influenced the growth and yield of crop. The treatment $\mathrm{T}_{2}\left(282 \mathrm{~kg}\right.$ urea ha $\left.{ }^{-1}\right)$ produced the highest grain yield $\left(5.34 \mathrm{t} \mathrm{ha}^{-1}\right)$. The $\mathrm{T}_{6}\left(94 \mathrm{~kg} \mathrm{urea} \mathrm{ha} \mathrm{k}^{-1}+1 \% \mathrm{urea}\right.$ solution FA) produced the highest straw yield $\left(6.58 \mathrm{t} \mathrm{ha}^{-1}\right)$ of the crop. The lowest grain yield $\left(3.20 \mathrm{t} \mathrm{ha} \mathrm{h}^{-1}\right)$ and the lowest straw yield $\left(4.19 \mathrm{t} \mathrm{ha}^{-1}\right)$ were recorded with $\mathrm{T}_{1}$ (control). Economic analysis showed that treatment $\mathrm{T}_{2}$ gave the highest marginal benefit cost ratio (7.65) while the lowest value (2.71) was observed with $T_{5}$ treatment. The overall results demonstrated that soil application of $282 \mathrm{~kg}$ urea ha $^{-1}$ was the best treatment for obtaining higher grain yield, higher nitrogen content of rice and higher marginal benefit cost ratio, and soil application is better than foliar application of urea.
\end{abstract}

Keywords: Urea, Nitrogen, Foliar application, Soil application

\section{Introduction}

Nitrogen is one of the major plant nutrients required for plant growth. For maximizing yield of rice, nitrogenous fertilizer is the kingpin in rice farming. It is essential for the synthesis of protein, which is the constituent of protoplasm and chloroplasts. It is a constituent of numerous important compounds found in living cells, including amino acid, protein (enzymes), nucleic acid and chlorophyll (Traore and Maranville, 1999). This element is the most essential element in determining the yield potential of intensified agriculture system (Mae, 1997). But nitrogen use efficiency is very low and the recovery of $\mathrm{N}$ in wetland rice seldom exceeds 40\% (De Datta and Buresh, 1989). Many factors determine the fertilizer efficiency for rice crop during cultivation such as soil, cultivar, season, environment, planting time, water management, weed control, cropping pattern, source, form, rate, time of application and method of application (De Datta, 1978). In many cases aerial spray of nutrients is preferred and gives quicker and better results than the soil application (Jamal et al., 2006). Recently foliar application of nutrients has become an important practice in the production of crops while application of fertilizers to the soil remains the basic method of feeding the majority of the crop plants. In this aspect, the present study was, therefore, undertaken to see the effect of soil and foliar application of urea on BRRIdhan 29.

\section{Materials and Methods}

The experiment was conducted at the Soil Science Field Laboratory of Bangladesh Agricultural University, Mymensingh during Boro season of 2009 with a view to evaluating the effect of foliar and soil application of urea- $\mathrm{N}$ on the yield and nutrient uptake of BRRIdhan 29. The soil belongs to the Sonatala soil series under the AEZ of Old Brahmaputra Floodplain. The soil was silty loam in texture having pH 6.8, organic matter content $1.82 \%$, total N $0.096 \%$, available P 8.0 ppm, exchangeable K $0.12 \mathrm{me} / 100 \mathrm{~g}$ soil and available $S 13.0 \mathrm{ppm}$. The experiment was laid out in a randomized complete block design (RCBD) with eight treatments and three replications. The treatments combinations were: $T_{1}$ (control), $T_{2}(282 \mathrm{~kg}$ urea ha $\left.{ }^{-1} \mathrm{SA}\right), \mathrm{T}_{3}$ (1\% urea solution $\left.\mathrm{FA}\right), \mathrm{T}_{4}$ (2\% urea solution $\left.\mathrm{FA}\right), \mathrm{T}_{5}(3 \%$ urea solution $\mathrm{FA}), \mathrm{T}_{6}(94 \mathrm{~kg}$ urea ha ${ }^{-1} S A+1 \%$ urea solution FA), $T_{7}\left(94 \mathrm{~kg}\right.$ urea ha ${ }^{-1} \mathrm{SA}+2 \%$ urea solution FA), $\mathrm{T}_{8}\left(94 \mathrm{~kg}\right.$ urea ha ${ }^{-1}$ $\mathrm{SA}+3 \%$ urea solution FA) where as SA means soil application and FA means foliar application. The amounts of urea applied were: $0,282,100,200,300,169,244,319 \mathrm{~kg} \mathrm{ha}^{-1}$, respectively. The total number of unit plots was 24 and the size of unit plot was $4 \mathrm{~m} \times 2.5 \mathrm{~m}$. Full doses of $\mathrm{P}, \mathrm{K}$ and $\mathrm{S}$ were 
applied to soil as basal @ 26, 60 and $10 \mathrm{~kg} \mathrm{ha}^{-1}$, respectively, during final land preparation. In $\mathrm{T}_{2}$, urea @ $282 \mathrm{~kg} \mathrm{ha}^{-1}$ was applied in 3 equal splits at 10, 30 and 55 DAT. For $T_{3}, T_{4}$ and $T_{5}$ treatments, foliar urea was applied at 10 days after transplanting for the $1^{\text {st }}$ time, then at 15 -day intervals for the $2^{\text {nd }}, 3^{\text {rd }}$ and $4^{\text {th }}$ times. For $T_{6}, T_{7}$ and $T_{8}$ treatments, $94 \mathrm{~kg}$ urea was applied after 10 DAT, followed by three sprays at 15day intervals. In each case of foliar spray, $2.5 \mathrm{~L}$ of urea solution was applied in $10 \mathrm{~m}^{2}$ plot $\left(2500 \mathrm{~L} \mathrm{ha}^{-1}\right)$. Forty days old seedlings were transplanted in the experimental plots with three seedlings hill $^{-1}$ with plant spacing of $15 \mathrm{~cm} \times 20 \mathrm{~cm}$. Intercultural operations were done whenever required. At maturity, the crop was harvested. Grain yield was recorded on $14 \%$ moisture basis and straw yield on sun-dry basis. The grain and straw samples were analyzed for nitrogen concentration. The nitrogen uptake was calculated from the $\mathrm{N}$ concentration and yield data. All the data were statistically analyzed by F-test and the mean differences were adjudged by Duncan's Multiple Range Test (DMRT).

\section{Results and Discussion}

The yield contributing characters such as plant height, panicle length, number of effective tillers hill ${ }^{-1}$ and number of grains panicle ${ }^{-1}$ of BRRIdhan 29 responded significantly to the treatments (Table 1 ). The tallest plant $(79.0 \mathrm{~cm})$ was observed in treatment $\mathrm{T}_{6}\left(94 \mathrm{~kg}\right.$ urea ha ${ }^{-1} \mathrm{SA}+1 \%$ urea FA) which was statistically similar to all other treatments except $T_{1}$ and $T_{3}$. The shortest plant $(65.6 \mathrm{~cm})$ was recorded with $T_{1}$ (control) treatment. The maximum number of effective tillers hill ${ }^{-1}(12.7)$ was found in $T_{8}\left(94 \mathrm{~kg}\right.$ urea ha ${ }^{-1}$ SA $+3 \%$ urea FA) which was statistically identical to the treatments $T_{2}, T_{5}$ and $T_{7}$ with the values of 12.1, $11.3,11.1$, respectively. The lowest number of tillers hill ${ }^{-1}(6.9)$ was found in $T_{1}$ (control). The panicle length varied from $20.6 \mathrm{~cm}$ to $24.7 \mathrm{~cm}$ due to different treatments. The largest panicle was observed in $\mathrm{T}_{2}$ (282 kg urea ha ${ }^{-1} \mathrm{SA}$ ). The shortest panicle was obtained in $\mathrm{T}_{1}$ (control) treatment. The number of grains panicle $^{-1}$ varied significantly from 88.3 to 141.5 . The highest number of grains panicle ${ }^{-1}$ was found in $T_{6}$ (94 kg urea ha $\mathrm{kA}^{-1} \mathrm{SA}$ urea solution FA) and the lowest number in $\mathrm{T}_{1}$ (control). Chopra and Chopra (2004) reported that nitrogen had significantly effects on yield attributes such as plant height, panicle plant ${ }^{-1}$ and 1000 -seed weight with increasing levels of $\mathrm{N}$ up to $120 \mathrm{~kg} \mathrm{~N} \mathrm{ha}^{-1}$ in rice.

Table 1. Effects of soil and foliar application of urea on the yield contributing characters of BRRIdhan 29

\begin{tabular}{|l|c|c|c|c|c|}
\hline Treatment & $\begin{array}{c}\text { Plant height } \\
(\mathrm{cm})\end{array}$ & $\begin{array}{c}\text { No. of effective } \\
\text { tillers } \\
\text { hill }^{-1}\end{array}$ & $\begin{array}{c}\text { Panicle } \\
\text { length } \\
(\mathrm{cm})\end{array}$ & $\begin{array}{c}\text { No. of } \\
\text { grains } \\
\text { panicle }\end{array}$ & $\begin{array}{c}1000-\text { grain } \\
\text { weight }(\mathrm{g})\end{array}$ \\
\hline $\mathrm{T}_{1}($ Control) & $65.6 \mathrm{c}$ & $6.9 \mathrm{~d}$ & $20.6 \mathrm{c}$ & $88.3 \mathrm{c}$ & 21.7 \\
\hline $\mathrm{T}_{2}(282 \mathrm{~kg}$ urea ha & & \\
\hline $\mathrm{T}_{3}(1 \%$ urea solution $\mathrm{FA})$ & $78.4 \mathrm{ab}$ & $12.1 \mathrm{a}$ & $24.7 \mathrm{a}$ & $134.4 \mathrm{a}$ & 22.20 \\
\hline $\mathrm{T}_{4}(2 \%$ urea solution FA) & $73.3 \mathrm{~b}$ & $8.8 \mathrm{c}$ & $22.6 \mathrm{~b}$ & $110.6 \mathrm{ab}$ & 22.1 \\
\hline $\mathrm{T}_{5}(3 \%$ urea solution FA) & $75.2 \mathrm{ab}$ & $10.0 \mathrm{bc}$ & $24.10 \mathrm{a}$ & $137.1 \mathrm{a}$ & 22.0 \\
\hline $\begin{array}{l}\mathrm{T}_{6}(94 \mathrm{~kg} \text { urea ha } \\
\text { urea solution FA) } \mathrm{SA}+1 \%\end{array}$ & $76.5 \mathrm{ab}$ & $11.3 \mathrm{ab}$ & $23.5 \mathrm{ab}$ & $127.2 \mathrm{ab}$ & 22.3 \\
\hline $\begin{array}{l}\mathrm{T}_{7}(94 \mathrm{~kg} \text { urea ha } \\
\text { urea solution FA) } \mathrm{SA}+2 \%\end{array}$ & $79.0 \mathrm{a}$ & $10.0 \mathrm{bc}$ & $24.1 \mathrm{a}$ & $141.5 \mathrm{a}$ & 21.8 \\
\hline $\begin{array}{l}\mathrm{T}_{8}(94 \mathrm{~kg} \text { urea ha } \\
\text { urea solution FA) }\end{array}$ & $77.5 \mathrm{ab}+3 \%$ & $11.1 \mathrm{ab}$ & $23.8 \mathrm{ab}$ & $123.8 \mathrm{ab}$ & 22.1 \\
\hline
\end{tabular}

Figures in a column having common letter(s) do not differ significantly at $5 \%$ level of significance.

Soil and foliar application of urea showed significant influence on grain yield of BRRIdhan 29 (Table 2). The highest grain yield $\left(5.34 \mathrm{t} \mathrm{ha}^{-1}\right)$ was recorded in $\mathrm{T}_{2}\left(282 \mathrm{~kg}\right.$ urea ha $\left.{ }^{-1} \mathrm{SA}\right)$ and the lowest yield (3.20 $\mathrm{t}$ ha $^{-1}$ ) in $T_{1}$ (control). Treatments $T_{4}$ and $T_{7}$ gave statistically similar yield but identical to $T_{2}$. The grain yields due to different treatments may be ranked in the order of $T_{2}>T_{7}>T_{4}>T_{6}>T_{8}>T_{5}>T_{3}>$ $\mathrm{T}_{1}$.Duhan and Singh (2002) showed that the yield and uptake were always higher with $120 \mathrm{~kg} \mathrm{ha}^{-1}$ than the lower rate of N. Chopra and Chopra (2000) reported that application of either 80 or $120 \mathrm{~kg} \mathrm{~N} \mathrm{ha}^{-1}$ improved the entire yield attributes compared with control. Results on grain yield reveal that application of $1 \%$ urea solution alone ( $46 \mathrm{~kg} \mathrm{~N} \mathrm{ha}^{-1}$ ) is not enough to produce good yield (4.09), while with $94 \mathrm{~kg}$ urea soil application $\left(112.24 \mathrm{~kg} \mathrm{~N} \mathrm{ha}^{-1}\right)$ the performance was better but still the yield were lower than that 
obtained with soil application alone $\left(\mathrm{T}_{2}\right)$. The reason might be a lower level of $\mathrm{N}$ for a successful plant growth. On the other hand, 3\% urea alone also showed poor performance compared to soil application of urea $\left(T_{2}\right)$ and even with $2 \%$ urea solution $\left(T_{4}\right.$ and $\left.T_{7}\right)$. The reason might be a higher level of $N$ for successful plant growth which causes negative effect. However, $2 \%$ urea solution $\left(92 \mathrm{~kg} \mathrm{~N}^{-1}\right)$ gave a statistically comparable yield with soil application of $130 \mathrm{~kg} \mathrm{~N} \mathrm{ha}^{-1}$. When it is applied alone $\left(\mathrm{T}_{4}\right) 38 \mathrm{~kg} \mathrm{~N}$ (82 kg urea) could be saved while when with soil application of $94 \mathrm{~kg}$ urea ( $\left.T_{7}\right)$ then $17 \mathrm{~kg} \mathrm{~N}$ (38 kg urea) could be saved. These two treatments could be alternative of soil application.

Table 2. Effects of soil and foliar application of urea on the grain and straw yield of BRRIdhan 29

\begin{tabular}{|c|c|c|c|c|}
\hline \multirow[t]{2}{*}{ Treatments } & \multicolumn{2}{|c|}{ Grain yield } & \multicolumn{2}{|c|}{ Straw yield } \\
\hline & t ha $^{-1}$ & $\begin{array}{c}\text { \% increase } \\
\text { over control }\end{array}$ & t ha $^{-1}$ & $\begin{array}{c}\% \text { increase over } \\
\text { control }\end{array}$ \\
\hline $\mathrm{T}_{1}$ (Control) & $3.20 \mathrm{e}$ & - & $4.19 \mathrm{c}$ & - \\
\hline $\mathrm{T}_{2}\left(282 \mathrm{~kg}\right.$ urea ha $\left.{ }^{-1} \mathrm{SA}\right)$ & $5.34 \mathrm{a}$ & 66.9 & $6.44 \mathrm{a}$ & 53.7 \\
\hline $\mathrm{T}_{3}(1 \%$ urea solution $\mathrm{FA})$ & $4.09 \mathrm{~d}$ & 27.8 & $5.41 \mathrm{~b}$ & 29.1 \\
\hline $\mathrm{T}_{4}(2 \%$ urea solution $\mathrm{FA})$ & $5.04 a b$ & 57.5 & $6.12 a b$ & 46.1 \\
\hline $\mathrm{T}_{5}(3 \%$ urea solution $\mathrm{FA})$ & $4.38 \mathrm{~cd}$ & 36.9 & $6.06 \mathrm{ab}$ & 44.6 \\
\hline $\mathrm{T}_{6}\left(94 \mathrm{~kg}\right.$ urea ha ${ }^{-1} \mathrm{SA}+1 \%$ urea solution FA) & $4.77 \mathrm{bc}$ & 49.06 & $6.58 \mathrm{a}$ & 57 \\
\hline $\mathrm{T}_{7}\left(94 \mathrm{~kg}\right.$ urea ha ${ }^{-1} \mathrm{SA}+2 \%$ urea solution FA) & $5.18 \mathrm{ab}$ & 61.9 & $6.34 \mathrm{a}$ & 51.3 \\
\hline $\mathrm{T}_{8}\left(94 \mathrm{~kg}\right.$ urea ha ${ }^{-1} \mathrm{SA}+3 \%$ urea solution $\left.\mathrm{FA}\right)$ & $4.63 \mathrm{bcd}$ & 44.68 & $6.47 \mathrm{a}$ & 54.4 \\
\hline
\end{tabular}

Figures in a column having common letter(s) do not differ significantly at $5 \%$ level of significance.

The grain $\mathrm{N}$ content varied from 0.97 to $1.17 \%$. The grain content was the highest in $\mathrm{T}_{5}$ (3\% urea FA). The control treatment $\left(\mathrm{T}_{1}\right)$ recorded the lowest grain $\mathrm{N}$ content. The $\mathrm{N}$ content in straw varied significantly due to different treatments. The straw $\mathrm{N}$ content ranged from 0.57 to $0.78 \%$, with the highest value observed in $\mathrm{T}_{7}$ (94 $\mathrm{kg}$ urea ha ${ }^{-1} \mathrm{SA}+2 \%$ urea FA) and the lowest $\mathrm{N}$ content in $\mathrm{T}_{1}$ (control). The $\mathrm{N}$ uptake by grain and straw of BRRIdhan 29 was significantly influenced by the different treatment combinations. The total uptake of $\mathrm{N}$ by grain and straw varied from $55.00 \mathrm{~kg} \mathrm{ha}^{-1}$ to $109.77 \mathrm{~kg} \mathrm{ha}^{-1}$. The highest total $\mathrm{N}$ uptake was observed in $\mathrm{T}_{2}$ (282 kg urea ha- $\mathrm{kA}^{-1}$ ) and the lowest $\mathrm{N}$ uptake in $\mathrm{T}_{1}$ (control). Prasad et al. (2007) reported that $\mathrm{N}$ at $120 \mathrm{~kg} \mathrm{ha}^{-1}$ resulted in higher $\mathrm{N}$ uptake compared to lower $\mathrm{N}$ levels.

Table 3. Effects of soil and foliar application of urea on nitrogen concentration and uptake of BRRIdhan 29

\begin{tabular}{|c|c|c|c|c|c|}
\hline \multirow[t]{2}{*}{ Treatments } & \multicolumn{2}{|c|}{$\mathrm{N}$ concentration (\%) } & \multicolumn{3}{|c|}{$\mathrm{N}$ uptake $\left(\mathrm{kg} \mathrm{ha}^{-1}\right)$} \\
\hline & Grain & Straw & Grain & Straw & Total \\
\hline $\mathrm{T}_{1}$ (Control) & 0.97 & $0.57 \mathrm{c}$ & $31.19 \mathrm{c}$ & $23.84 \mathrm{~d}$ & $55.00 \mathrm{c}$ \\
\hline $\mathrm{T}_{2}\left(282 \mathrm{Kg}\right.$ urea ha $\left.{ }^{-1} \mathrm{SA}\right)$ & 1.14 & $0.75 \mathrm{a}$ & $61.01 \mathrm{a}$ & $48.74 \mathrm{a}$ & $109.76 \mathrm{a}$ \\
\hline $\mathrm{T}_{3}(1 \%$ urea solution $\mathrm{FA})$ & 1.03 & $0.67 \mathrm{~b}$ & $42.47 \mathrm{~b}$ & $36.69 \mathrm{c}$ & $79.16 \mathrm{~b}$ \\
\hline $\mathrm{T}_{4}(2 \%$ urea solution $\mathrm{FA})$ & 1.00 & $0.77 \mathrm{a}$ & $50.74 \mathrm{ab}$ & $47.17 \mathrm{a}$ & $97.93 \mathrm{a}$ \\
\hline $\mathrm{T}_{5}(3 \%$ urea solution $\mathrm{FA})$ & 1.17 & $0.73 \mathrm{ab}$ & $51.39 \mathrm{ab}$ & $44.42 \mathrm{ab}$ & $95.80 \mathrm{a}$ \\
\hline $\mathrm{T}_{6}\left(94 \mathrm{~kg}\right.$ urea ha ${ }^{-1} \mathrm{SA}+1 \%$ urea solution $\left.\mathrm{FA}\right)$ & 1.14 & $0.61 \mathrm{c}$ & $54.81 \mathrm{a}$ & $40.01 \mathrm{bc}$ & $94.83 \mathrm{a}$ \\
\hline $\mathrm{T}_{7}\left(94 \mathrm{~kg}\right.$ urea ha ${ }^{-1} \mathrm{SA}+2 \%$ urea solution $\left.\mathrm{FA}\right)$ & 1.10 & $0.78 \mathrm{a}$ & $57.23 \mathrm{a}$ & $49.69 \mathrm{a}$ & $106.93 \mathrm{a}$ \\
\hline $\mathrm{T}_{8}\left(94 \mathrm{~kg}\right.$ urea ha ${ }^{-1} \mathrm{SA}+3 \%$ urea solution $\left.\mathrm{FA}\right)$ & 1.09 & $0.72 a b$ & $50.72 a b$ & $46.84 \mathrm{a}$ & $97.56 \mathrm{a}$ \\
\hline
\end{tabular}

Figures in a column having common letter(s) do not differ significantly at $5 \%$ level of significance.

The economic performance of different treatments was evaluated through economic analysis. The analysis showed that the highest gross return (Tk 81790) was obtained from $T_{2}$ and the lowest one (Tk 49923) was from $T_{1}$ treatment. The analysis also showed that the highest variable cost was obtained in $T_{5}$ (Tk 5200) and the lowest one in treatment $T_{3}$ (Tk 2800). Marginal gross margin also varied due to different treatments. The highest marginal gross margin was obtained (TK 28183) from $T_{2}$ treatment and the lowest one (Tk 11234) was obtained from $\mathrm{T}_{3}$ treatment. The highest and lowest marginal benefit cost ratio was recorded from the treatment $T_{2}$ (7.65) and $T_{5}$ (2.71), respectively. Sudhakar et al. (2001) found that there was a significant increase grain yield, straw yield, net return and B:C ratio with each increment of nitrogen application up to $125 \mathrm{~kg} \mathrm{ha}^{-1}$. 
The overall results indicate that $T_{2}$ treatment $\left(282 \mathrm{~kg}\right.$ urea ha $\left.{ }^{-1}\right)$ gave the highest yield. Treatments $T_{4}$ and $\mathrm{T}_{7}$ gave a statistically comparable yield with treatment $T_{2}$. These two treatments could be alternative of soil application. But in these two treatments, total variable cost is higher (Tk 4000 and Tk 4228, respectively) than that in $T_{2}$ treatment (Tk 3684). On the other hand, marginal benefit cost ratio was the highest in $T_{2}$ treatment (7.65). From the above discussion it can be stated that treatment $T_{2}$ is the best in terms of obtaining higher grain yield and from the economic point of view, and soil application is not replaceable by foliar application.

Table 4. Economic analysis of BRRIdhan 29 production

\begin{tabular}{|c|c|c|c|c|c|}
\hline Treatment & $\begin{array}{c}\text { Gross } \\
\text { return } \\
\left(\mathrm{Tk} \mathrm{ha}^{-1}\right)\end{array}$ & $\begin{array}{c}\text { TVC } \\
\left(\text { Tk ha }^{-1}\right)\end{array}$ & $\begin{array}{c}\text { Gross } \\
\text { margin } \\
\left(\mathrm{Tk} \mathrm{ha}^{-1}\right)\end{array}$ & $\begin{array}{c}\text { Marginal gross } \\
\text { margin } \\
\left(\mathrm{Tk} \mathrm{ha}^{-1}\right)\end{array}$ & MBCR \\
\hline $\mathrm{T}_{1}$ (Control) & 49923 & - & 49923 & - & - \\
\hline $\mathrm{T}_{2}\left(282 \mathrm{Kg}_{\mathrm{rea} \mathrm{ha}} \mathrm{ha}^{-1} \mathrm{SA}\right)$ & 81790 & 3684 & 78106 & 28183 & 7.65 \\
\hline $\mathrm{T}_{3}(1 \%$ urea solution $\mathrm{FA})$ & 63957 & 2800 & 61157 & 11234 & 4.01 \\
\hline $\mathrm{T}_{4}(2 \%$ urea solution $\mathrm{FA})$ & 77310 & 4000 & 73310 & 23387 & 5.84 \\
\hline $\mathrm{T}_{5}(3 \%$ urea solution $\mathrm{FA})$ & 69225 & 5200 & 64025 & 14102 & 2.71 \\
\hline $\mathrm{T}_{6}\left(94 \mathrm{~kg}\right.$ urea ha ${ }^{-1} \mathrm{SA}+1 \%$ urea solution $\left.\mathrm{FA}\right)$ & 75335 & 3328 & 72007 & 22084 & 6.63 \\
\hline $\mathrm{T}_{7}\left(94 \mathrm{~kg}\right.$ urea ha ${ }^{-1} \mathrm{SA}+2 \%$ urea solution $\left.\mathrm{FA}\right)$ & 79595 & 4228 & 75367 & 25444 & 6.01 \\
\hline $\mathrm{T}_{8}\left(94 \mathrm{~kg}\right.$ urea ha ${ }^{-1} \mathrm{SA}+3 \%$ urea solution $\left.\mathrm{FA}\right)$ & 73352 & 5128 & 68224 & 18301 & 3.56 \\
\hline
\end{tabular}

TVC: Total variable cost

MBCR: Marginal benefit cost ratio

\section{Conclusion}

The application of $282 \mathrm{~kg}$ urea ha ${ }^{-1}$ is the best treatment in terms of both obtaining higher grain yield and economic performance. The results of the study also indicate that soil application is better than foliar application. However, further investigation is necessary to draw a definite conclusion.

\section{Acknowledgements}

The research work was funded by Bangladesh Agricultural University Research System (BAURES).This contribution is gratefully acknowledged.

\section{References}

Chopra, N.K. and Chopra, N. 2004. Seed yield and quality of "Pusa 44" rice (Oryza sativa) as influenced by nitrogen fertilizer and raw spacing. Indian. J. Agril. Sci., 74(3): 144-146.

Chopra, N.K. and Chopra, N. 2000. Effect of row spacing and N level on growth, yield and seed quality of scented rice (Oryza sativa) under transplanted conditions. Indian. J. Agron., 45(2): 304-308.

De Datta, S.K. and Buresh, R.J. 1989. Integrated Nitrogen Management in Irrigated Rice. Adv. Soil Sci., 10: $143-169$.

De Datta, S.K. 1978. Fertilizer Management for Efficient Use in Wetland Rice Soils. In F.N. Ponnamperuma, ed. Soil and Rice. p. 671-670. Intl. Rice Res. Inst. Los Banos, Philippines.

Jamal, Z., Hamayun, M., Ahmad, N. and Chaudhary, M.F. 2006. Effect of soil and foliar application of different concentrations of NPK and foliar application of $\left(\mathrm{NH}_{4}\right)_{2} \mathrm{SO}_{4}$ on different parameters in wheat. J. Agron., 5(2): 251-256.

Mae, T. 1997. Physiological Nitrogen Efficiency in Rice: Nitrogen Utilization, Photosynthesis and Yield Potential. In T. Ando, K. Fujita, T. Mae, H. Matsumoto, S. Mori and J. Sekiya, eds. Plant Nutrition for Sustainable Food Production and Environment, p. 51-60. Kluwer Academic Publishers, Dordrecht, The Netherlands.

Prasad, S.K., Singh, A.K. and Das, S.N. 2007. Effect of water deficit and N levels on yield, N-uptake and nutrient balance in rice (Oryza sativa). Int. J. Agril. Sci., 3(1): 209-212

Sudhakar, G., Solamalai, A. and Rasisankar, N. 2001. Yield and economic of semidry rice as influenced by cultivars and levels of nitrogen. Indan. J. Dryland Agril. Res. Develop., 16(1): 42-44.

Traore, A. and Maranville, J.W. 1999. Nitrate reductase activity of diverse grain sorghum genotypes and its relationship to nitrogen use efficiency. Agron. J., 91: 863-869. 